\title{
The Gap between Attitudes and Behavior in Ethical Consumption: A Critical Discourse
}

\author{
Pragya Budhathoki ${ }^{1,2^{*},}$ Kabita Adhikari ${ }^{1}$ and Ranjana Koirala ${ }^{3}$
}

1 Quest International College, Pokhara University, Nepal

2 Loan Specialist, Home Loan Expert Nepal, Lalitpur, Nepal

3 Psychiatric Nursing, Maharajgunj Nursing Campus, Tribhuvan University, Kathmandu, Nepal Corresponding Author (budhathokipragya@gmail.com)

Received:22 Sept, 2019

Revised: $25 \mathrm{Nov}, 2019$

Accepted: 17 Dec, 2019

Published: $28 \mathrm{Jan}, 202 \mathrm{O}$

How to cite this paper: $B u d h a-$ thoki, P., Adhikari, K. \&Koirala, $R$. (2019). The gap between attitudes and behavior in ethical consumption: A critical discourse. Quest Journal of Management and Social Sciences, 1(2), 285-295.

Copyright (C) 2019 by authors and Quest Journal of Management and Social Sciences

This work is licensed under a Creative Commons Attribution-NonCommercial-NoDerivatives 4.0 International License.

https://creativecommons.org/licenses/ by-nc-nd/4.0/

\begin{abstract}
Background: Although consumers are increasingly concerned with ethical factors when forming product opinions and making purchase decisions, recent studies have highlighted significant differences between consumers' ethical consumption intentions and their actual buying behavior. Various dimensions concerning how consumers make purchase and consumption decisions and the driving forces behind them have been identified through this study.
\end{abstract}

Objectives: This paper aims to explore the factors leading the gap between attitudes and behavior of consumers in relation to ethical consumption.

Methods: The desk review carried out on various related studies reflects that the factors that obstruct the process of ethical consumption and thereby being responsible in forming attitude-behavior gap, which can be helpful in the course of management decision implications worth encouragement of ethical consumption behavior. Moreover, conceptual framework that has been developed for ethical consumption also indicates the factors responsible for creating ethical intention-behavior gap.

Findings: This study derives concepts on ethical consumption from literature survey and identifies consumers' understanding level on ethical consumption. Likewise, the study also provides a comprehensive picture of factors impeding ethical consumption among consumers while providing some theoretical and analytical applications.

Conclusions: Price, quality, taste, brand image of products and convenience are some of the considerable issues while buying, due to which consumers' ethical concerns towards society and environment are not transformed into their consumption behavior.

Keywords: ethics, consumers, ethical consumption, buying behavior, social norms, perceived behavior

Paper Type: Review Paper

JEL Classification: $\mathrm{K}_{32}, \mathrm{~K}_{3} 8$ 


\section{Introduction}

A few researchers have specifically addressed the issue concerning consumer perception on ethics since the mid-1990s. Ethical consumption is a form of consumer activism that is expressed when consumers purchase goods and services from socially responsible companies and refrain purchasing from unethical companies (Giesler \& Veresiu, 2014). Ethical consumption is composed of five steps that include recognition of a need, searching for information, evaluation of alternatives, purchase decision and evaluation of purchase (Akehurst et al, 2012). Oh \& Yoon (2014) have stated that emotional manifestations like self-esteem related with doing good for the society may lead to ethical consumption. At present, consumers' focus from quality and price of product is shifting towards ethical values, transforming them from rational consumers to ethical consumers. These ethical consumers advocate for the consumption of ethical products and services that do not involve any kind of labor exploitation and pose no harms on animals, humans and the environment as a whole (Huh, 2011). In this way, ethical consumption may be defined as the process of conscientious consumption that includes purchase decisions based on personal values and moral beliefs by taking into consideration not only self-interest but the well-being of society and natural environment too (Oh \& Yoon,2014).

According to Thompson (2009), due to the development in information and communications technology, consumers' concern for society and environment has increased and encouraged ethical consumption. Another study conducted by De Pelsmacker et al. (2005) depicts that apart from individual consumers, community and the natural environment benefits through ethical consumption. This study further suggests that people or the environment locally as well as globally may benefit through ethical consumption. Likewise, study findings of Griskevicius, Tyber \& Van den Bergh (2010) provide evidences that ethical consumption has a positive impact on individual consumer's self-identify and their health.

A study conducted by Carrigan \& Attalla (2001) showed that the major predecessor of ethical consumption is the price of ethically produced goods. In the same way, the findings of another study conducted by Shaw \& Shui (2002) indicate that subjective norm, attitude, perceived behavioral control, ethical identity and ethical obligation influence ethical consumption. Whereas, factors like perceived behavioral control and subjective norm were found to be less influential. Oh \& Yoon (2014) found that ethical obligation, self-identity and altruism had been predominantly used as the effective antecedents of previous research to predicting various types of ethical consumption. This paper aims to explore the factors leading the gap between attitude and behavior of consumers in relation to ethical consumption.

The paper is organized as follows. In the next section, we provide a short review of the related literature. Section 3 presents a discussion. The final section concludes the study.

\section{Review of Literature}

\section{Consumer's buying behavior}

Consumers' buying behavior is the study of how individuals make decision related to their consumption activities by making use of available resources namely, time, effort and mon- 
ey. It is concerned with understanding various dimensions concerning what consumers buy, how they buy, why they buy, when they buy, from where they buy and how often they buy (Kumar, 2016). The buying behavior of consumer passes through five stages beginning from recognition of problem, followed by searching information, evaluating the alternatives, purchase of goods and ending with post-purchase behavior (Rani, 2014). Consumers' buying behavior is influenced by five factors namely, psychological, social, economic, and cultural and personal factors (Ramya \& Ali, 2016). Paudel et al. (2018) observed that such buying behavior is largely influence by socio-cultural and economic factors.

In the present context, consumers have shown considerable interest for consumption of products with high nutritional value and produced without any harm to the society and environment (Sharma, Uprety \& Phuyal, 2016). Trustworthy information about the food content is an important determinant of consumption behavior. The display of relevant information in the product label increases the product's likelihood of being purchased (Kraus, Annunziata \& Vecchio, 2017). Most of the consumption decisions especially in the grocery items are guided by the need to be satiated and fed with nutrients. Various allergies and intolerances towards food products have encouraged consumers to consider healthier options in relation to food consumption (Asioli et al., 2017). Consumers are increasingly concerned about the components used in the food products due to the recent trends of health consciousness and sustainability (Rana \& Paul, 2017). Organically produced and environmentally sustainable are the major factors taken into consideration by ethically concerned consumers to make consumption decisions (Sebastiani, Montagnini \& Dalli, 2013). Consumers' ethical concerns towards society and environment are not only transformed into their consumption behavior. Other factors like price, quality, ingredients, brand image of products and convenience play more significant role in consumption behavior (Ghvanidze, Velikova, Dodd \& Oldewage-Theron, 2016).

\section{Theories on consumer's buying behavior}

In order to conduct this study, various theories on ethical consumption have been used, namely: theory of reasoned action, theory of planned behavior, modified theory of planned behavior, theory of ethical consumerism and norm activation model theory. The theory of reasoned action explains that consumers' intention to behave in a certain manner is influenced by their attitude and subjective norms (Macovei, 2015). The theory of planned behavior presents a cognitive progression that attitudes are determined by beliefs, the determined attitude leads to intentions and those intentions from behavior (Chatzidakis, Hibbert \& Smith, 2007); (De Pelsmacker \& Janssens, 2007). In the same way, intentions and behavior are moderated by social norms and behavioral control. Similarly, modified theory of planned behavior explains that self-identity of consumers plays an important role in explaining their ethical purchasing intention (Shaw, Shiu and Clarke, 2000). Therefore, for explaining the ethical purchasing intention of consumers more effectively, it includes two additional measures 'ethical obligation' and 'self-identity', not included in the original theory of planned behavior. Theory of ethical consumerism deals with understanding the roles played by demographics, attitudes and psychographics of consumers in ethical consumption behavior (Cho \& Krasser, 2011). 
A variety of factors that can provide an in-depth reasoning behind ethical consumption intention and behavior, not included in previous models, have been considered in this theory. Likewise, according to the norm activation model theory, when an individual becomes aware of the adverse consequences and attribution of responsibility for not acting in favor of the environment, norm activation begins. The individual then makes an analysis of the problem identified and the consequences of his behavioral action with motivation, after evaluating the abilities to make a difference (Bliesner et al., 2013).

\section{Empirical studies on consumer's buying behavior}

Studies on ethical consumption carried out by different researchers during different time periods and nations were reviewed. During the 1990's, consumers were inclined towards ethical consumption due to pressure group support and communication media (Strong, 1996). Despite this, consumers' ethical behavior was not guaranteed at all times due to their consideration towards product taste (Grankvist \& Biel, 2001). The reason was lack of service providers' concern towards interpersonal issues concerning empathy, assurance and responsiveness (Thomas et al., 2002). McGoldrick \& Freestone (2008); Bissinger \& Leufkens (2017) argue that consumers are willing to pay premium price for ethical products. Table 1 illustrates empirical studies in different regions covered by this study:

Table 1: Empirical Studies

\begin{tabular}{|c|c|c|c|c|}
\hline Author & Study & Method & Result/ Findings & $\begin{array}{l}\text { Conclusion/ } \\
\text { Recommendation }\end{array}$ \\
\hline Creyer (1997), USA & $\begin{array}{l}\text { Perspective } \\
\text { of customers } \\
\text { regarding the } \\
\text { corporate behavior }\end{array}$ & $\begin{array}{l}\text { Descriptive } \\
\text { Analysis }\end{array}$ & $\begin{array}{l}\text { Customers pay higher } \\
\text { prices for ethical } \\
\text { products. }\end{array}$ & $\begin{array}{l}\text { Ethical behavior rewards } \\
\text { sellers and unethical } \\
\text { behavior harms their } \\
\text { business. }\end{array}$ \\
\hline $\begin{array}{l}\text { Abratt \& Penman } \\
\text { (2002), South } \\
\text { Africa }\end{array}$ & $\begin{array}{l}\text { Salespersons' } \\
\text { ethics and factors } \\
\text { affecting them. }\end{array}$ & $\begin{array}{l}\text { Inferential } \\
\text { Analysis }\end{array}$ & $\begin{array}{l}\text { Controversial practices } \\
\text { against customers } \\
\text { were considered as less } \\
\text { ethical than against } \\
\text { competitors. }\end{array}$ & $\begin{array}{l}\text { Salespersons bear a deep } \\
\text { sense of loyalty towards } \\
\text { their employers as } \\
\text { compared to customers } \\
\text { when dealing with them. }\end{array}$ \\
\hline $\begin{array}{l}\text { Uusitalo \& } \\
\text { Oksanen (2004), } \\
\text { Finland }\end{array}$ & $\begin{array}{l}\text { Consumers' } \\
\text { perspective } \\
\text { on ethical } \\
\text { consumerism }\end{array}$ & $\begin{array}{l}\text { Descriptive } \\
\text { analysis }\end{array}$ & $\begin{array}{l}\text { Majority of consumers } \\
\text { consider ethics as } \\
\text { an important part of } \\
\text { business. }\end{array}$ & $\begin{array}{l}\text { Ethics influences the } \\
\text { consumers' purchasing } \\
\text { and consumption } \\
\text { decisions. }\end{array}$ \\
\hline $\begin{array}{l}\text { Eckhardt et al. } \\
\text { (2010), }\end{array}$ & $\begin{array}{l}\text { Why don't } \\
\text { consumers } \\
\text { consume ethically? }\end{array}$ & $\begin{array}{l}\text { In-depth } \\
\text { interview }\end{array}$ & $\begin{array}{l}\text { Using moral appeals } \\
\text { and information to } \\
\text { evoke ethical purchasing } \\
\text { behavior doesn't work at } \\
\text { all times. }\end{array}$ & $\begin{array}{l}\text { In order to promote } \\
\text { ethical consumption, it } \\
\text { needs to be mandated } \\
\text { by institutions and the } \\
\text { government itself. }\end{array}$ \\
\hline $\begin{array}{l}\text { Megicks et al. } \\
\text { (2012), England }\end{array}$ & $\begin{array}{l}\text { Factors responsible } \\
\text { for influencing } \\
\text { the intended } \\
\text { and actual } \\
\text { consumption } \\
\text { behavior of } \\
\text { consumers }\end{array}$ & $\begin{array}{l}\text { Focus } \\
\text { groups }\end{array}$ & $\begin{array}{l}\text { Four major drivers of } \\
\text { ethical consumption } \\
\text { are local support and } \\
\text { provenance, intrinsic } \\
\text { quality, shopping } \\
\text { benefits, buying } \\
\text { inconvenience and } \\
\text { product distracters. }\end{array}$ & $\begin{array}{l}\text { Local support and } \\
\text { provenance should be } \\
\text { incorporated into all } \\
\text { in-store, external and on- } \\
\text { pack messages. }\end{array}$ \\
\hline
\end{tabular}




\begin{tabular}{|c|c|c|c|c|}
\hline Author & Study & Method & Result/ Findings & $\begin{array}{l}\text { Conclusion/ } \\
\text { Recommendation }\end{array}$ \\
\hline $\begin{array}{l}\text { Pezhman et al. } \\
\text { (2013), Iran }\end{array}$ & $\begin{array}{l}\text { How ethical } \\
\text { behavior impacts } \\
\text { consumer loyalty } \\
\text { and satisfaction in } \\
\text { Persian Insurance } \\
\text { Company }\end{array}$ & $\begin{array}{l}\text { Structural } \\
\text { equation } \\
\text { modeling }\end{array}$ & $\begin{array}{l}\text { Ethical sales behavior } \\
\text { has a significant impact } \\
\text { on customer satisfaction, } \\
\text { customer trust and } \\
\text { customer satisfaction } \\
\text { has a significant impact } \\
\text { on customer trust and } \\
\text { loyalty. }\end{array}$ & $\begin{array}{l}\text { To increase customer } \\
\text { trust and loyalty, } \\
\text { ethical behavior should } \\
\text { be increased by the } \\
\text { company. }\end{array}$ \\
\hline $\begin{array}{l}\text { Sharma (2015), } \\
\text { India }\end{array}$ & $\begin{array}{l}\text { Impact of retailing } \\
\text { ethics on customer } \\
\text { satisfaction in } \\
\text { Indian retail } \\
\text { sector. }\end{array}$ & $\begin{array}{l}\text { Exploratory } \\
\text { and } \\
\text { confirmatory } \\
\text { factor } \\
\text { analysis }\end{array}$ & $\begin{array}{l}\text { Honesty, respect } \\
\text { and recognition, fair } \\
\text { treatment from retailers } \\
\text { is a determining factor } \\
\text { of satisfaction. }\end{array}$ & $\begin{array}{l}\text { When retailers behave } \\
\text { honestly, it enhances } \\
\text { customer satisfaction } \\
\text { leading to increased } \\
\text { sales, positive word } \\
\text { of mouth, customer } \\
\text { retention and strong } \\
\text { reputation in the market. }\end{array}$ \\
\hline Tuan (2015) & $\begin{array}{l}\text { Impact of ethical } \\
\text { sales behavior on } \\
\text { customer loyalty }\end{array}$ & $\begin{array}{l}\text { Structural } \\
\text { equation } \\
\text { modeling }\end{array}$ & $\begin{array}{l}\text { Ethical sales behavior } \\
\text { has a positive impact } \\
\text { on customer trust and } \\
\text { customer commitment, } \\
\text { leading to customer } \\
\text { commitment and loyalty }\end{array}$ & $\begin{array}{l}\text { Customer commitment } \\
\text { has direct effect on } \\
\text { customer loyalty but } \\
\text { ethical sales behavior } \\
\text { only has an indirect effect } \\
\text { on customer loyalty. }\end{array}$ \\
\hline $\begin{array}{l}\text { Iglesias et al. } \\
(2019)\end{array}$ & $\begin{array}{l}\text { Impact of } \\
\text { customers' } \\
\text { perceptions of } \\
\text { brand ethicality on } \\
\text { the brand equity. }\end{array}$ & $\begin{array}{l}\text { Structural } \\
\text { equation } \\
\text { modeling }\end{array}$ & $\begin{array}{l}\text { Customer perceived } \\
\text { ethicality has a positive } \\
\text { and indirect impact on } \\
\text { brand equity }\end{array}$ & $\begin{array}{l}\text { Brand heritage, brand } \\
\text { image and recognition } \\
\text { benefits have a role in } \\
\text { determining customer } \\
\text { perceptions of brand } \\
\text { ethicality. }\end{array}$ \\
\hline $\begin{array}{l}\text { Zollo et al. (2018), } \\
\text { USA }\end{array}$ & $\begin{array}{l}\text { Role of moral } \\
\text { intuition in ethical } \\
\text { purchase and } \\
\text { consumption }\end{array}$ & $\begin{array}{l}\text { Correlation } \\
\text { coefficient, } \\
\text { scale } \\
\text { reliability } \\
\text { and } \\
\text { descriptive } \\
\text { statistics }\end{array}$ & $\begin{array}{l}\text { Inferential intuition has } \\
\text { significant influence } \\
\text { on ethical concerns as } \\
\text { compared to affective } \\
\text { intuition. }\end{array}$ & $\begin{array}{l}\text { Moral reasoning is } \\
\text { complemented by moral } \\
\text { intuition in ethical } \\
\text { decision making. }\end{array}$ \\
\hline Ferrell et al. (2019) & $\begin{array}{l}\text { Relationship } \\
\text { between } \\
\text { corporate social } \\
\text { responsibility, } \\
\text { ethics and brand } \\
\text { attitude. }\end{array}$ & $\begin{array}{l}\text { Structural } \\
\text { equation } \\
\text { modeling }\end{array}$ & $\begin{array}{l}\text { Ethics has more impact } \\
\text { on brand attitudes } \\
\text { than corporate social } \\
\text { responsibility. }\end{array}$ & $\begin{array}{l}\text { Efforts should be made } \\
\text { by companies to maintain } \\
\text { ethical behavior in } \\
\text { addition to emphasizing } \\
\text { corporate social } \\
\text { responsibility. }\end{array}$ \\
\hline
\end{tabular}

Negassa (2015) has emphasized that the likelihood of the brand to function increases and has a positive impact on organizational performance (Fernández \& Pinuer, 2016) when customers perceive a company to be ethical. However, factors like lack of information and credibility of the existing information create barriers in ethical consumption (Carrigan et al., 2004); (Bray et al. 2011); (Clever \& Felix, 2014); (Wiederhold \& Martinez, 2018). Therefore, emphasis should be given to encourage ethical consumption by identifying the factors that impede the process. 


\section{Conceptual Framework}

Consumers are increasingly concerned with ethical factors when forming their opinions about products and making purchase decisions (Brayet al., 2010). Several previous studies, Shaw Shiu (2002) and Zollo (2018) have revealed that consumers are actively considering factors related to supporting fair trade, labor rights, environment protection, welfare of animals, organically produced food products, boycotting products from unethical producers and others before making their purchasing and consumption decisions.

Macovei (2015) stated that consumers' intention to behave in a certain matter is influenced by their actual behavior. Their behavior in turn is guided by attitude and subjective norms. According to Fishbein \& Ajzen (1980), three core determinants of consumer behavior are perception of social norms, attitude and perceived behavior control upon which the consumer behavior models are built. The theory of planned action explains the inter-linkages between beliefs, attitude, intention and behavior of consumers. It has been stated that attitude of consumers is guided by their beliefs which determines their behavior and purchase intentions. Likewise, Harrison et al. (2005) have stated that in addition to these previously mentioned variables, other variables like ethical obligation and self-identity of consumers play a significant role in determining their ethical consumption behaviors. Ethical consumerism was emerged as a part of social activism under which consumers' purchasing and consumption behavior are not guided solely by their personal motives but are in consideration with the well-being of society and environment as a whole. The figure depicts the conceptual framework related to ethical consumption by consumers.

In the present context, the intention of consumers to purchase ethically produced products is more driven by their sense of ethical obligation and identity rather than other self-motivated concerns (Shaw et al., 2000). During the decision making process, consumers' values play a much important role than product price and brand choice (Vermeir \& Verbeke, 2006).

Consumers were found to be less guided by post-purchase consequences than their values and principles when making decisions related to ethical purchasing (Vitell et al., 2001). Likewise, consumers who display characteristics related to benevolence, honesty, self-direction, idealism and universalism are more inclined towards ethical consumption as compared to consumers placing higher values to security, conformity, power, ambition and hedonism (Vermeir \& Verbeke, 2004).

Furthermore, clear and reliable information has a great significance in guiding the consumers' purchase decisions (Paudel et al., 2018) as lack of information regarding ethical products and their resulting benefits often act as barrier to ethical consumption (Dickson, 2001). Different patterns of consumption are displayed by consumers belonging to different socio-demographic segments as their views towards products and their consumption are shaped by their age, gender, occupation and income (Essoo \& Dibb, 2004). However, with a large number of research mostly concentrated on qualitative and conceptual research, empirical and explanatory perspectives are lacking in the area of ethical consumption of products. 


\section{Discussion}

Ethical consumption has emerged as an important subject matter of study as it deals with ethical production, consumption and disposal activities minimizing the amount of harm posed on communities, animals and environment as a whole. Due to the development in information and communications technology, consumers' concern for society and environment has increased and encouraged ethical consumption (Carrigan \& Attalla, 2001). Paudel and Devkota (2018) opined that effective level of communication makes purchase much better. Firms are also getting engaged in ethical management of their production and distribution activities due to their impact on company's goodwill in the long run (Oh \& Yoon, 2014). Another study conducted by Pelsmacker et al. (2015) depicts that apart from businesses, consumers, community and the natural environment also benefit through ethical consumption. However, the understanding and implementation of ethical production and consumption activities in the context of developing countries is still slow-paced due to several factors like political instability, increasing corruption and poor of implementation of laws encouraging healthy business environment (Baseline Study Report, 2013). This is also due to the differences in buying behavior of people in different countries that is largely influenced by five factors, namely: psychological, social, economic, and cultural and personal factors (Ramya \& Ali,2016).

Figure 1: Conceptual Framework for Ethical Consumption

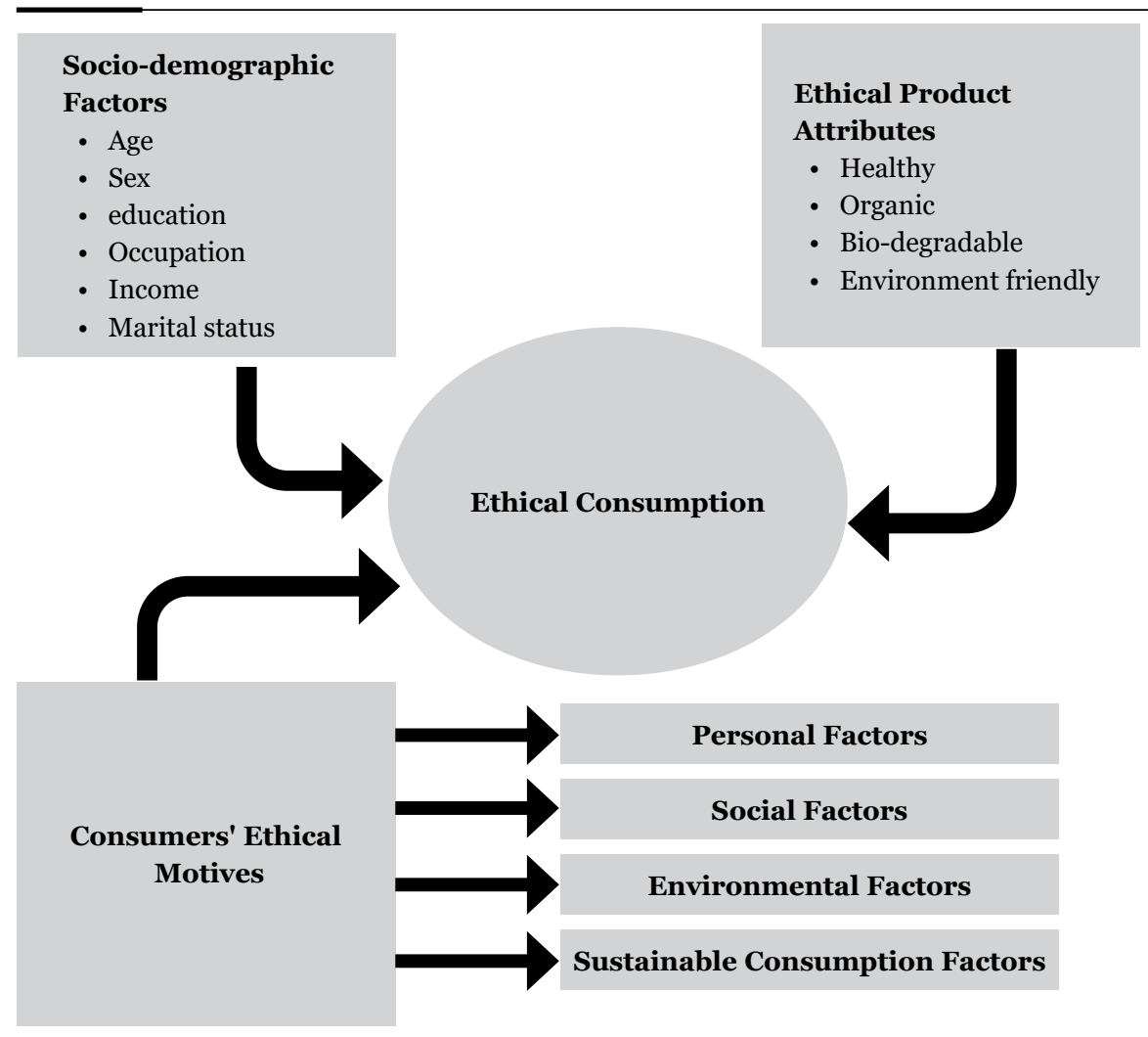


Price, lack of information and quality perception are the factors responsible for obstructing ethical consumption of products (Bray et al., 2011). Likewise, consumers give more preference to issues related to well-being and health than other factors for ethical consumption (Burke et al., 2014). Other related studies have found that ethical consumption behavior is influenced by price, lack of information, credibility of existing information, ethical self-identity and moral norms (O'Connor et al., 2017). The studies further emphasize that in order to encourage ethical consumption, consumers need to be provided proper information on the need for ethical consumption, resulting benefits and clear any misconceptions regarding price and quality of ethical products. There should be constant improvement in information flow with the consumers to remove the attitude-behavior gap (Wiederhold, 2018).

\section{Conclusion}

The literature review carried out on various related studies reflects on several factors that obstruct the process of ethical consumption. The difference between consumers' attitude towards ethical products and their actual consumption behavior, which is known as the ethical gap, is also understood through the review. Various studies have found that consumers attitude towards ethical consumption and actual behavior differs across countries resulting from the differences in terms of psychological, social, economic and other personal factors. Because of this, the same factors are not found to be influential towards ethical consumption. In this regard, factors like price of products, subjective norms, and attitude were found to be the drivers of ethical gap in several countries. Whereas, lack of products' information, unavailability of products, lack of convenience were found to impede ethical consumption in some other countries. Several studies have been carried out to identify these factors impeding ethical consumption of products globally. However, despite the increasing concern for ethical production and distribution practices around the globe, there seems to be a research gap in this area in context of developing countries. This implies that ethical consumption is still a subject of study that is to be explored.

\section{Acknowledgement}

Earlier version of this paper has been presented at International Business Conference (IBC, 2019) in Mid-western University, Surkhet, Nepal dated 14th-15th July 2019.

\section{Conflict of Interest}

No conflict of interest existed while preparing this paper.

\section{References}

Abratt, R., \& Penman, N. (2002). Understanding factors affecting salespeople's perceptions of ethical behavior in South Africa. Journal of Business Ethics, 35(4), 269-280.

Akehurst, G., Afonso, C. and Martins Gonçalves, H. (2012). Re-examining green purchase behaviour and the green consumer profile: new evidences, Management Decision, 50 (5), 972-988.

Asioli, D., Aschemann-Witzel, J., Caputo, V., Vecchio, R., Annunziata, A., Næs, T., \& Varela, P. (2017). Making sense of the "clean label" trends: A review of consumer food choice behavior and discus- 
sion of industry implications. Food Research International, 99, 58-71.

Baseline study report on Namabia. (2013). Retrieved from https://www.ombudsman.org.na/wpcontent/uploads/2016/o9/Baseline_Strudy_Human_Rights_2013.pdf

Bissinger, K., \& Leufkens, D. (2017). Ethical food labels in consumer preferences. British Food Journal, 119(8), 1801-1814.

Bliesner, A., Liedtke, C., Welfens, M., Baedeker, C., Hasselkuß, M., \& Rohn, H. (2014). Norm-oriented interpretation learning and resource use: The concept of "open-didactic exploration" as a contribution to raising awareness of a responsible resource use. Resources, 3(1), 1-30.

Bray, J., Johns, N., \& Kilburn, D. (2011). An exploratory study into the factors impeding ethical consumption. Journal of Business Ethics, 98(4), 597-608.

Carrigan, M. \& Attalla, A. (2001), The myth of the ethical consumer-do ethics matter in purchase behaviour?. Journal of Consumer Marketing, 18(7), 560-578.

Carrigan, M., Szmigin, I., \& Wright, J. (2004). Shopping for a better world? An interpretive study of the potential for ethical consumption within the older market. Journal of Consumer Marketing, 21(6), 401-417.

Chatzidakis, A., Hibbert, S., \& Smith, A. P. (2007). Why people don't take their concerns about fair trade to the supermarket: The role of neutralization. Journal of Business Ethics, 74, 89-100. doi: 10.1007/s10551-006-9222-2

Cho, S., \& Krasser, A. H. (2011). What makes us care? The impact of cultural values, individual factors, and attention to media content on motivation for ethical consumerism. International Social Science Review, 86(1/2), 3-23.

Clever, V., \& Felix, C. Evaluating product ethics in grocery retailing: The view of Harare customers. Greener Journal of Business and Management Studies, 4(4), 138-145.

Creyer, E. H. (1997). The influence of firm behavior on purchase intention: do consumers really care about business ethics? Journal of Consumer Marketing, 14(6), 421-432.

De Pelsmacker, P., \& Janssens, W. (2007). A model for fair trade buying behaviour: The role of perceived quantity and quality of information and of product-specific attitudes. Journal of business ethics, 75(4), 361-380.

De Pelsmacker, P., Driesen, L., \& Rayp, G. (2005). Do consumers care about ethics? Willingness to pay for fair-trade coffee. Journal of Consumer Affairs, 39(2), 363-385.

Dickson, M. A. (2001). Utility of no sweat labels for apparel consumers: Profiling label users and predicting their purchases. Journal of Consumer Affairs, 35(1), 96-119.

Eckhardt, G. M., Belk, R., \& Devinney, T. M. (2010). Why don't consumers consume ethically?. Journal of Consumer Behaviour, 9(6), 426-436.

Essoo, N., \& Dibb, S. (2004). Religious influences on shopping behaviour: an exploratory study. Journal of Marketing Management, 2O(7-8), 683-712.

F. Burke, P., Eckert, C., \& Davis, S. (2014). Segmenting consumers' reasons for and against ethical consumption. European Journal of Marketing, 48(11/12), 2237-2261.

Fernández, L. M. V., \& Pinuer, F. J. V. (2016). Influence of customer value orientation, brand value, and business ethics level on organizational performance. Revista Brasileira de Gestão de Negócios, 18(59), 5-23.

Ferrell, O. C., Harrison, D. E., Ferrell, L., \& Hair, J. F. (2019). Business ethics, corporate social responsibility, and brand attitudes: An exploratory study. Journal of Business Research, 95, 491-501.

Fishbein, M. \& Ajzen, I. (1980). Understanding Attitudes and Predicting Social Behavior. Prentice-Hall, Englewood Cliffs, NJ. 
Ghvanidze, S., Velikova, N., Dodd, T. H., \& Oldewage-Theron, W. (2016). Consumers' environmental and ethical consciousness and the use of the related food products information: The role of perceived consumer effectiveness. Appetite, 107, 311-322

Giesler, M. and Veresiu, E. (2014). Creating the responsible consumer: moralistic governance regimes and consumer subjectivity. Journal of Consumer Research, 41(3), 840-857.

Grankvist, G., \& Biel, A. (2001). The importance of beliefs and purchase criteria in the choice of eco-labeled food products. Journal of Environmental Psychology, 21(4), 405-410.

Griskevicius, V., Tybur, J. M. \& Van den Bergh, B. (2010). Going green to be seen: status, reputation, and conspicuous conservation. Journal of Personality and Social Psychology, 98(3), 392.

Hamelin, N., Harcar, T., \& Benhari, Y., (2013). Ethical consumerism: A view from the food industry in Morocco. Journal of Food Products Marketing, 19(5), 343-362.

Harrison, R., Newholm, T. \& Shaw, D. (2005). The Ethical Consumer. Sage.

Huh, E.J. (2011). Analysis of attitude and purchase intention regarding. Ethical Korean Journal of Consumer Studies, 22, 89-111.

Iglesias, O., Markovic, S., Singh, J. J., \& Sierra, V. (2019). Do customer perceptions of corporate services brand ethicality improve brand equity? Considering the roles of brand heritage, brand image, and recognition benefits. Journal of Business Ethics, 154(2), 441-459.

Kraus, A., Annunziata, A., \& Vecchio, R. (2017). Socio-demographic factors differentiating the consumer and the motivations for functional food consumption. Journal of the American College of Nutrition, 36(2), 116-126.

Kumar, A. A. (2016). Factors Influencing Customers Buying Behavior. Global Journal of Management and Business Research, 16(3).

Macovei, O. I. (2015). Applying the theory of planned behavior in predicting proenvironmental behaviour: The case of energy conservation. Acta Universitatis Danubius. Economica, 11(4), 15-32.

McGoldrick, P. J., \& Freestone, O. M. (2008). Ethical product premiums: antecedents and extent of consumers' willingness to pay. The International Review of Retail, Distribution and Consumer Research, 18(2), 185-201.

Megicks, P., Memery, J., \& Angell, R. J. (2012). Understanding local food shopping: Unpacking the ethical dimension. Journal of Marketing Management, 28(3-4), 264-289.

Negassa, G. J. (2015). The effects of business ethics on consumers' perceptions of merchandizing and service giving businesses in Mekelle, Ethiopia. International Journal of Scientific and Research Publications, 547.

O'Connor, E. L., Sims, L., \& White, K. M. (2017). Ethical food choices: Examining people's Fair Trade purchasing decisions. Food quality and preference, 6o, 105-112.

Oh, J.C. \& Yoon, S.J. (2014). Theory-based approach to factors affecting ethical consumption. International Journal of Consumer Studies, 38(3), 278-288.

Paudel, U. R., \& Devkota, N. (2018). Socio-Economic influences on small business performance in Nepal-India open border: Evidence from cross-sectional analysis. Economics \& Sociology, 11(4), 11-30.

Paudel, U. R., Devkota, N., \& Bhandari, U. (2018). Socio-Cultural and economic factors in cross-border purchase: A study of customers' perspective in Sunauli-Nepal/India border. Modern Economy, 9(6), 1089-1102.

Pezhman, R., Javadi, M. H. M., \& Shahin, A. (2013). Analyzing the influence of ethical sales behavior on customer loyalty through customer satisfaction and trust in insurance company. International Journal of Academic Research in Business and Social Sciences, 3(9), 754.

Ramya, N., \& Mohamed Ali, S. A. (2016). Factors affecting consumer buying behavior. International 
journal of applied research, 2(10), 76-80.

Rana, J., \& Paul, J. (2017). Consumer behavior and purchase intention for organic food: A review and research agenda. Journal of Retailing and Consumer Services, 38, 157-165.

Rani, P. (2014). Factors affecting consumer behavior. International Journal of Current Research and Academic Review, 2(9), 52-61.

Sebastiani, R., Montagnini, F. \& Dalli, D. (2013). Ethical consumption and new business models in the food industry evidence from the Italy case. Journal of Business Ethics, 114(3), 473-488.

Sharma, B. R. (2015). Edifying retailer-wholesaler ethical relationship: A basis for good governance in retail sector. Journal of Commerce and Accounting Research, 4(3).

Sharma, P., Uprety, P., \& Phuyal, R. K. (2016). An Analysis of consumer's purchase behavior on organic foods in Kathmandu valley. Advances in Economics and Business Management (AEBM), 3(5), 514-526.

Shaw, D., \& Shiu, E. (2002). The role of ethical obligation and self-identity in ethical consumer choice. International Journal of Consumer Studies, 26(2), 109-116.

Shaw, D., Shiu, E., \& Clarke, I. (2000). The contribution of ethical obligation and self-identity to the theory of planned behaviour: An exploration of ethical consumers. Journal of marketing management, 16(8), 879-894.

Strong, C. (1996). Features contributing to the growth of ethical consumerism-a preliminary investigation. Marketing Intelligence \& Planning, 14(5), 5-13.

Thomas, J. L., Vitell, S. J., Gilbert, F. W., \& Rose, G. M. (2002). The impact of ethical cues on customer satisfaction with service. Journal of retailing, 78(3), 167-173.

Thompson, C. B. (2009). Descriptive data analysis. Air Medical Journal, 28(2), 56-59.

Tuan, N. M. (2015). The impact of ethical sales behavior on customer loyalty: A case from Vietnam. International Journal of Business and Management, 10(3), 152.

Uusitalo, O., \& Oksanen, R. (2004). Ethical consumerism: A view from Finland. International Journal of Consumer Studies, 28(3), 214-221.

Vermeir, I., \& Verbeke, W. (2004). Sustainable food consumption: Exploring the consumer attitude-behaviour gap (Ghent University, Working Paper No. 4, 268). Retrieved from http://citeseerx.ist.psu.edu/viewdoc/download?doi=10.1.1.130.1110\&rep=rep1\&type $=$ pdf

Vermeir, I., \& Verbeke, W. (2006). Sustainable food consumption: Exploring the consumer "attitudebehavioral intention" gap. Journal of Agricultural and Environmental Ethics, 19(2), 169-194.

Vitell, S. J., Singhapakdi, A., \& Thomas, J. (2001). Consumer ethics: an application and empirical testing of the Hunt-Vitell theory of ethics. Journal of Consumer Marketing, 18(2), 153-178.

Wiederhold, M., \& Martinez, L. F. (2018). Ethical consumer behavior in Germany: The attitude-behaviour gap in the green apparel industry. International Journal of Consumer Studies, 42(4), 419-429.

Zollo, L., Yoon, S., Rialti, R., \& Ciappei, C. (2018). Ethical consumption and consumers' decision making: The role of moral intuition. Management Decision, 56(3), 692-710. 